\title{
Prevalence of antibodies to Chlamydophila abortus in ovines in the Londrina area of Paraná state, Brazil
}

\section{Prevalência de anticorpos contra Chlamydophila abortus em ovinos da região de Londrina, Paraná, Brasil}

\author{
Bruna Azevedo de Carvalho Lima ${ }^{1}$; Kledir Anderson Hofstaetter Spohr ${ }^{1}$; \\ Francielle Gibson da Silva Zacarias'; ${ }^{2}$ Sergio Mangano de Almeida Santos ${ }^{3}$; \\ Mario de Luca Neto ${ }^{3}$; Carlo Turilli ${ }^{4}$; Julio Cesar de Freitas ${ }^{5 *}$
}

\begin{abstract}
The aim of this paper was to estimate the prevalence of antibodies to Chlamydophila abortus in ewes from the Londrina region of Paraná state. Blood samples from 267 adult ewes from eight herds were submitted to complement fixation testing. Tests were considered positive when the titers $\geq 32$. Nineteen animals $(7.11 \%)$ in $7(87.50 \%)$ herds tested positive for antibodies against $C$. abortus. The titers were 32 in 17 animals and were 64 and 128 in the other two animals. The clinical signs recorded were abortion, stillbirth, weak newborns and heat repetition. The high frequency of herds with at least one positive animal and a seroprevalence of $7.11 \%$ suggest the presence of Chlamydophila abortus in the animals of studied herds.
\end{abstract}

Key words: Chlamydiosis, complement fixation test, ovine enzootic abortion, seroprevalence

\section{Resumo}

O objetivo deste trabalho foi estimar a prevalência de anticorpos anti-Chlamydophila abortus em ovinos de propriedades localizadas na região de Londrina, estado do Paraná. A prova de fixação de complemento foi realizada em 267 amostras de soro sanguíneo de ovinos adultos, provenientes de oito propriedades e foram considerados positivos os soros com títulos $\geq 32$. Em sete $(87,50 \%)$ propriedades foram detectados $19(7,11 \%)$ animais positivos, sendo 17 com títulos de 32, um com 64 e outro com 128. Nestas propriedades, os sinais clínicos descritos foram abortamentos, natimortalidade, nascimento de crias fracas e repetição de cio. A elevada frequência de propriedades com pelo menos um animal positivo e a ocorrência de $19(7,11 \%)$ animais positivos na prova de fixação de complemento sugerem a presença de Chlamydophila abortus nos animais das propriedades estudadas.

Palavras-chave: Clamidiose, teste de fixação de complemento, aborto enzoótico ovino, soroprevalência

\footnotetext{
${ }^{1}$ Discentes do Programa de Pós-Graduação em Ciência Animal, Dept ${ }^{\circ}$ de Medicina Veterinária Preventiva, Universidade Estadual de Londrina, UEL, Londrina, PR, Brasil. E-mail: brunaclima@yahoo.com.br; andklei@yahoo.com.br

${ }^{2}$ Prof Adjunta do Curso de Medicina Veterinária, Universidade Estadual do Norte do Paraná, UENP, Bandeirantes, PR. Brasil. E-mail: franciellegs@uenp.edu.br

${ }^{3}$ Discentes do Curso de Medicina Veterinária, UEL, Londrina, PR, Brasil. E-mail: sergio.uel@hotmail.com; mariodeln@yahoo. com.br

${ }^{4}$ Pesquisador Sênior do Programa de Pós-Graduação em Ciência Animal, Dept ${ }^{\mathrm{o}}$ de Medicina Veterinária Preventiva, UEL, Londrina, PR, Brasil. E-mail: c.turilli@izs.it

${ }^{5}$ Prof. Titular, Dept ${ }^{\circ}$ de Medicina Veterinária Preventiva, UEL, Londrina, PR, Brasil. E-mail: freitasj@uel.br

* Author for correspondence
} 


\section{Introduction}

Chlamydophila spp may cause diseases such as reproductive disorders, encephalitis, pneumonia, enteritis, polyarthritis and conjunctivitis and may cause asymptomatic infections in sheep, goats, cattle and swine (OIE, 2004).

Ovine enzootic abortion (OEA) caused by Chlamydophila abortus (C. abortus) is the major cause of abortion in ovines and goats in many countries, leading to great economic losses (WANG; SHIEH; LIAO, 2001; SZEREDI; BACSADI, 2002; SHARMA et al., 2003; MASALA et al., 2005).

In ewes, OEA results in necrotic placentitis, and depending on the extension of damage, abortion may occur during the final trimester of pregnancy. Thus, premature or weak lambs may be born. In males, vasculitis, epididymitis and orchitis can occur (RODOLAKIS; SALINAS; PAPP, 1998; GOMES et al., 2001).

OEA easily disseminates through the flock, especially during the birthing season when great amounts of bacteria are dispersed into the environment with the placenta and uterine discharges (AITKEN; CLARKSON; LINKLATER, 1990). Generally, only a few cases of abortion are observed during the first year after the introduction of OEA into a flock. However, this number may increase to $30 \%$ or more, thus increasing the number of premature and weak newborn births. After the first year, the prevalence rate stays from 5 to $10 \%$ if the infected animals are not treated (LONGBOTTOM; COULTER, 2003). Primary infected sheep only exhibit clinical signs during the next pregnancy (AITKEN, 2000).

In addition to its economical impact, $C$. abortus has known zoonotic potential and may cause infertility or abortion in women who are exposed to it (MEIJER et al., 2004; WALDER et al., 2003).

In Brazil, the scarcity of studies on the occurrence of C. abortus in sheep prevents an accurate assessment of its prevalence. The aim of this paper was to estimate the prevalence of antibodies to $C$. abortus in ewes raised in Londrina region of Paraná state.

\section{Materials and Methods}

Among a total of 2,630 sheep belonging to eight herds in the region of Londrina, blood samples were taken from 267 reproductive age ewes, $\geq 12$ mo old, between November and December 2005. The properties housing the herds were ranked from A to $\mathrm{H}$, and the inclusion criterion was the registration of each property with the Agriculture, Livestock and Provision Secretary (Secretaria de Agricultura e Abastecimento do Paraná - SEAB) of Londrina. All properties were technified, with herds ranging from 100 to 950 animals. The size of the sample was calculated using the EPI-INFO-6,4 software (DEAN et al., 1994) with an estimated prevalence of $50 \%$, an error of $5 \%$ and a confidence level of $95 \%$. The size of each sampling was proportional to each property's flock and the ewes were chosen randomly.

The blood draw was performed by jugular venipuncture with an anti-clot sterile vacuum device after treating the puncture area with iodated alcohol. The blood was kept at room temperature until clot formation and retraction. The serum was them collected, split into two aliquots and stored in $\mathrm{a}-20^{\circ} \mathrm{C}$ freezer.

Anti-Chlamydophila abortus antibodies were detected using a complement fixation test in 96-well titration microplates, as recommended by Donn et al. (1997).

The antigen for the complement fixation test was obtained from the C. abortus S26/3 reference strain and was titrated against ovine serum to a titer of 512 (positive control). Bovine fetal serum was used as a negative control $\left(\mathrm{GIBCO}^{\circledR}\right.$ - USA).

Blood from healthy ovines obtained from the Veterinary Hospital of Universidade Estadual de Londrina, Paraná state, Brazil, was added to an 
equal volume of Alsever's solution and stored in 10 $\mathrm{ml}$ aliquots at $4^{\circ} \mathrm{C}$. The erythrocytes were diluted in $2 \%$ veronal buffer $\left(\mathrm{CAMBREX}^{\circledR}\right)$ and used within 5 days.

Hemolysin $\left(\right.$ Laborclin $^{\circledR}$ ) was stored at $-20^{\circ} \mathrm{C}$ and diluted in two hemolytic units prior to use.

The hemolytic system was prepared by adding equal volumes of hemolysin and the $2 \%$ erythrocyte solution and incubating the mixture at $37^{\circ} \mathrm{C}$ for 15 minutes to sensitize the erythrocytes.

Guinea pig complement $\left(\right.$ Laborclin $^{\circledR}$ ) was diluted in veronal buffer, under ice bath, titrated and stored at $-20^{\circ} \mathrm{C}$. Prior to its use, it was diluted into two units.

The complement fixation test was performed by adding $25 \mu \mathrm{L}$ of serum to $25 \mu \mathrm{L}$ of antigen and 25 $\mu \mathrm{L}$ of complement. The microplates were agitated for 2 minutes and incubated at $37^{\circ} \mathrm{C}$ for 30 minutes. After adding $25 \mu \mathrm{L}$ of the hemolytic system, the microplates were incubated again under the conditions used for the first part of the test.

Each microplate was made in duplicate, and antigen was not added to the second plate. This allowed us to evaluate the anticomplement properties of the tested serum. The hemolytic system, erythrocyte control and antigen in the absence or presence of complement were monitored in all plates.

The plates were read visually. A positive reaction was recorded when erythrocyte agglutination could be observed, and hemolysis indicated a negative reaction.

Serum titers equal to or greater than 32 were considered positive (OIE, 2004) and were diluted in veronal buffer solution in base 2 until 1024.

\section{Results}

Of the 267 tested serum samples, 19 (7.11\%) from seven different herds (animals from herd $\mathrm{H}$ were negative) were positive: six (19.35\%) from herd A, one $(6.25 \%)$ from herd B, three $(20.00 \%)$ from $\mathrm{C}$, two (18.18\%) from $\mathrm{D}$, one $(10.00 \%)$ from $\mathrm{E}$, four $(5.88 \%)$ from $\mathrm{F}$ and two (1.98\%) from $\mathrm{G}$. All of the positive serum samples had titers of 32 , except for two animals from ranch $G$ that had titers of 64 and 128 .

\section{Discussion}

It was observed that the prevalence of $C$. abortus in the region of Londrina $(7.11 \%)$ is lower than what has been reported worldwide. Nevertheless, prevalence found was similar to that reported by epidemiologic other seroepidemiological surveys performed in Brazil. Piatti, Scarcelli and Genovez (2006) found $12 \%$ prevalence in goats from São Paulo, Mato Grosso, Minas Gerais and Bahia, and all sheep tested in their study were found to be negative for $C$. abortus. Pereira et al. (2009) also reported $12 \%$ prevalence in goats and $8.10 \%$ in sheep in Pernambuco. Pinheiro Jr et al. (2010) and Farias et. al. (2013), respectively, reported a prevalence of $21.50 \%$ in sheep from Alagoas state and a prevalence of $19.7 \%$ in sheep from the semiarid region of Paraíba state, while Salaberry et al. (2010) found a prevalence of 3.30\% in sheep from Uberlândia county, Minas Gerais state. In Paraná state, only one survey of the prevalence of Chlamydophila spp has been conducted, and the researchers found a prevalence of $1.42 \%$ in cattle from properties with a history of reproductive disorders (SILVA-ZACARIAS et al., 2009).

Variability in the rate of abortion occurrence in the studied population, in which the registries were obtained from the properties and not from each individual, may partially explain the low frequency of positive animals and detected titers reported in this paper. According to Wilsmore, Parsons and Dawson (1984), serum conversion occurs in the first weeks after primary infection; however, the initial antibody titers are low and transient. Antibody titers increase and persist for several months only after abortion. 
A cross-reaction between $C$. abortus and other species of the Chlamydiaceae family, especially $C$. pecorum, or other Gram-negative bacteria may result in false positive results (OIE, 2004). We adopted the OIE (2004) cut-off criteria and considered animals with titers equal to or greater than 32 to be positive. Titers below 32 were considered to be non-specific for $C$. abortus, although they also could have been the result of a mild $C$. abortus infection. Al-Qudah et al. (2004) demonstrated that C. pecorum may be found in the intestines of some ovines without any pathological manifestation but with minimal antibody production compared to C. abortus. False positive results due to vaccination were not considered because the $C$. abortus vaccine is not available in Brazil.

Six of the seven positive herds had reports of abortion and stillbirth, four had heat repetition reports and three reported weak newborns. Shewen (1980) considered these reports to be the most important signs of OEA. All of the tested animals in herd $\mathrm{H}$ were negative in the complement fixation test, but this herd also had reports of stillbirth and heat repetition.

Despite reports of reproductive problems on all of the examined properties, the serum titers showed the presence of $C$. abortus in seven of the eight studied herds. New epidemiologic studies of OEA must be conducted to obtain more widespread data regarding this disease in Brazil to determine whether it is necessary to adopt prophylactic strategies.

\section{Acknowledgments}

Conselho Nacional de Desenvolvimento Científico e Tecnológico (CNPQ - Scientific and Technological development National Council), Fundação Araucária de Apoio ao Desenvolvimento Científico e Tecnológico do Paraná (Paraná's Scientific and Technological development and support $\backslash$ Araucária Foundation) and Professor José da Silva Guimarães Junior and Milton Hissashi Yamamura.

\section{References}

AITKEN, I. D. Chlamydial abortion. In: MARTIN, W. B.; AITKEN, I. D. Disease of sheep. 3. ed. Oxford: Blackwell Science, 2000. p. 81-86.

AITKEN, I. D.; CLARKSON, M. J.; LINKLATER, K. Enzootic abortion of ewes. Veterinary Record, London, v. 10, n. 6, p. 136-138, 1990.

AL-QUDAH, K. M.; SHARIF, L. A.; RAOUF, R. Y.; HAILAT, N. Q.; AL-DOMY, F. M. Seroprevalence of antibodies to Chlamydophila abortus show in Awassi sheep and local goats in Jordan. Veterinary Medicine, Barcelona, v. 49, n. 12, p. 460-466, 2004.

DEAN, A. G.; DEAN, J. A.; COULOMBIER, D.; BRENDEL, K. A.; SMITH, D. C.; BURTON, A. H.; DICKER, R. C.; SUlLIVAN, K.; FAGAN, R. F.; ARNER, T. G. Epi Info, version 6: a word processing, data base and statistics program for epidemiology on microcomputers. Atlanta: Centers for Disease Control and Prevention, 1994. $589 \mathrm{p}$.

DONN, A.; CARNIELETTO, P.; CHIARACANE, G.; LADU, M.; MATCHELL, J.; MANDOLA, M. L.; RUIU, A.; STANCANELLI, A.; TURILLI, C. Standardizzazione della tecnica di fissazione del complemento per la dimostrazione di anti-Chlamydia nel siero de sangue. $I L$ Progresso Veterinario, Torino, n. 4, p. 125-128, 1997.

FARIAS, A. E. M.; HIGINO, S. S. S.; AZEVEDO, S. S.; COSTA, D. F.; SANTOS, F. A.; SANTOS, C. S. A. B.; PIATTI, R. M.; ALVES, C. J. Caracterização epidemiológica e fatores de risco associados à infecção por Chlamydophila abortus em ovinos deslanados do semiárido brasileiro. Pesquisa Veterinária Brasileira, Seropédica, v. 33, n. 3, p. 286-290, 2013.

GOMES, M. J. P. O; WALD, V. B. O.; MACHADO, R. D. O.; SILVEIRA, M. C. Isolamento de Chlamydia psittaci em touros com vesiculite seminal, no Rio Grande do Sul. A Hora Veterinária, Porto Alegre, v. 20, n. 119, p. 43-46, 2001.

LONGBOTTOM, D.; COUlter, L. J. Animal chlamidiosis and zoonotic implication. Journal of Comparative Pathology, Bristol, v. 128, n. 4, p. 217-244, 2003.

MASALA, G.; PORCU, R.; SANNA, G.; TANDA, A., TOLA, S. Role of Chlamydophila abortus in ovine and caprine abortion in Sardinia, Italia. Veterinary Research Communication, Philadelphia, v. 29, n. 1, p. 117-123, 2005.

MEIJER, A.; BRANDENBURG, A.; DE VRIES, J.; BEENTJES, J.; ROHOLL, P. Chlamydophila abortus infection in a pregnant woman associated with indirect 
contact with infected goats. European Journal of Clinical Microbiology \& Infectious Diseases, Berlin, v. 23, n. 6, p. 487-90, 2004.

PEREIRA, M. F.; PEIXOTO, R. M.; PIATTI, R. M.; MEDEIROS, E. S.; MOTA, I. O.; AZEVEDO, S. S.; MOTA, R. A. Ocorrência e fatores de risco para Chlamydophila abortus em ovinos e caprinos no estado de Pernambuco. Pesquisa Veterinária Brasileira, Seropédica, v. 29, n. 1, p. 33-40, 2009.

PIATTI, R. M.; SCARCELLI, E. P.; GENOVEZ, M. E. Pesquisa de anticorpos anti-Chlamydophila em caprinos e ovinos. Biológico, São Paulo, v. 68, p. 138-140, 2006. Suplemento 2 .

PINHEIRO, J. W.; MOTA, R. A.; PIATTI, R. M.; OLIVEIRA, A. A. F.; SILVA, A. M.; ABREU, S. R. O.; ANDERLINI, G. A.; VALENÇA, R. M. B. Seroprevalence of antibodies to Chlamydophila abortus in ovine in the State of Alagoas, Brazil. Brazilian Journal of Microbiology, São Paulo, v. 41, n. 2, p. 358-364, 2010.

RODOLAKIS, A.; SALINAS, J.; PAPP, J. Recent advances on ovine chlamydial abortion. Veterinary Research, Ghent, v. 29, n. 3-4, p. 275-288, 1998.

SALABERRY, S. R. S.; LARA, M. C. C. S. H.; PIATTI, R. M.; NASSAR, A. F. C.; CASTRO, J. R.; GUIMARÃES, E. C.; LIMA-RIBEIRO, A. M. C. Prevalência de anticorpos contra os agentes da MaediVisna e clamidofilose em ovinos no município de Uberlândia, MG. Arquivos do Instituto Biológico, São Paulo, v. 77, n. 3, p. 411-417, 2010.

SHARMA, S. P.; BAIPOLEDI, E. K.; NYANGE, J. F. C.; TLAGAE, L. Isolation of Toxoplasma Gondii from goats with history of reproductive disorders and the prevalence of Toxoplasma and Chlamydial antibodies. Onderstepoort Journal of Veterinary Research, Pretoria, v. 70, p. 65-68, 2003.
SHEWEN, P. E. Chlamydial infection in animals: a review. Canadian Veterinary Journal, Guelph, v. 21, n. 1, p. 2-11, 1980.

SILVA-ZACARIAS, F. G.; SPOHR, K. A. H.; LIMA, B. A. C.; DIAS, J. A.; MÜLLER, E. E.; FERREIRA NETO, J. S.; TURILLI, C.; FREITAS, J. C. Prevalência de anticorpos anti-Chlamydophila spp. em propriedades rurais com histórico de aborto bovino no estado do Paraná. Pesquisa Veterinária Brasileira, Seropédica, v. 29, n. 3, p. 215-219, 2009.

SZEREDI, L.; BACSADI,A. Detection of Chlamydophila (Chlamydia) abortus and Toxoplasma gondii in smears from cases of ovine and caprine abortion by streptavidinbiotin method. Journal of Comparative Pathology, London, v. 127, n. 4, p. 257-263, 2002.

WALDER, G.; MEUSBURGER, H.; HOTZEL, H.; OEHME, A.; NEUNTEUFEL, W.; DIERICH, M. P.; WÜRZNER, R. Chlamydophila abortus pelvic inflammatory disease. Emerging Infectious Diseases, Atlanta, v. 9, n. 12, p. 1642-1644, 2003.

WANG, F. I.; SHIEH, H.; LIAO, Y. K. Prevalence of Chlamydophila abortus infection in domesticated ruminants in Taiwan. Journal of Veterinary Science, Tokyo, v. 63, n. 11, p. 1215-1220, 2001.

WILSMORE, A. J.; PARSONS, V.; DAWSON, M. Experiments to demonstrate routes of transmission of ovine enzootic abortion. The British Veterinary Journal, London, v. 140, n. 4, p. 380-391, 1984.

WORLD ORGANIZATION FOR ANIMAL HEALTH OIE. Ovine chlamydiosis. In: OIE. Manual of standards for diagnostic tests and vaccines. $6^{\text {th }}$ ed. Paris: OIE, 2008. Available at: http://www.oie.int/manual-of-diagnostictests-and-vaccines-for-terrestrial-animals/ $>$. Accessed at: 7 mar. 2013. 
